\title{
SUBALTERN PLANET OF CULTURAL STUDIES
}

\author{
Charlie Samuya Veric \\ De La Salle University, Manila, Philippines \\ csveric@yahoo.com
}

\begin{abstract}
A contribution to a mostly unwritten history, the essay provides a preliminary account of cultural studies in Asia, Africa, and Latin America from decolonization to globalization. My intention is two-fold, namely, to contribute to the history of cultural studies in the global South and experiment with the writing of planetary history to determine the lessons that can be learned when totality is imagined from below. I argue that whether it is the geopolitics of decolonization in Asia, the politics of indigenization in Africa, or the critique of knowledge-production in Latin America, cultural studies signifies the unfinished task of decolonization.

Keywords

cultural studies, postcolonial, planetarity

About the author

Poet, essayist, and translator, Charlie Samuya Veric holds a PhD in American Studies from Yale University where he was a member of the Working Group on Globalization and Culture, the Initiative on Race, Gender, and Globalization, and the Photographic Memory Workshop. An Associate Professor of Literature at De La Salle University-Manila, his most recent work includes the English translation of E. San Juan's poems, Mahal Magpakailanman (2011). He is currently revising his dissertation on the representations of the face in the context of modernity.
\end{abstract}

Almost a decade after the dismantling of the Department of Cultural Studies and Sociology at the University of Birmingham, the field has never been more robust given the newest buzzword: global cultural studies. ${ }^{1}$ As must be clear, the origins of such global dreams go as far back as the years leading to the closure of the Birmingham School when Jon Stratton and Ien Ang tried to see cultural studies in an international frame. ${ }^{2}$ But the notion itself was inchoate in that the subjects of analysis, whether in Urbana-Champaign or Fremantle, remained bound up with the nationstate. Michael Denning has a recent riff on this argument, suggesting that the imagination of transnational cultural studies requires the mapping of its practices in the age of globalization. For Denning, moreover, transnational cultural studies cannot be divorced from what he calls critical globalization studies whose task is the "elaboration of a transnational history of the age of three worlds" (27).

To date, however, this history remains unwritten, especially the part that relates to the last and least of the three worlds, the global South. As Ackbar Abbas and John Nguyet Erni point out, cultural studies beyond North America, Europe, and Australia remains unknown despite its 
transnational context as a practice. ${ }^{3}$ If Denning argues that the transnational history of cultural studies in the age of three worlds has yet to be written, Abbas and Erni accordingly suggest that the intellectual geography of the international future of cultural studies has yet to be charted.

This work gestures toward the writing of that uncharted history, one that gleans from the past and future of what Che Guevarra in 1964 once called the millions of inhabitants of Asia, Africa, and Latin America who had risen to meet a new life. What happens, then, if we imagine the history of cultural studies not from London, New York, or Paris, but from Manila, Kampala, and Caracas? That is, what utopia can be apprehended when universal history is imagined from the edges of the world? In this essay, I will provide a provisional history of cultural studies as a planetary practice from decolonization to the age of globalization in Asia, Africa, and Latin America. ${ }^{4}$ My intention is two-fold. First, I hope to contribute to the history of cultural studies in the global South. Second, I want to experiment with the writing of planetary history to determine the lessons that can be learned when totality is imagined from below. To do this, I will focus on the leading forms of intellectual exchange in the academic profession - journals, monographs, anthologies, manifestos, and debates - that relate to the origins and rise of cultural studies in the global South.

Let me be clear about what this project is not, however. To begin with, I am not in any way offering an exhaustive account of postcolonial cultural studies. Quite the opposite, my intent is to do a "distant reading," an approach that I take from Franco Moretti who argues that distance itself is a condition of knowledge. In this paradigm, the aspiration is much more sweeping, one that looks for constellations and recurrences in place of singularities. That is to say, my goal is not to focus on a single case and derive from it a general theory of postcolonial cultural studies, but to analyze themes, movements, tropes, and systems that are far bigger and messier than any one case. In a word, my aim is to map postcolonial cultural studies by zooming out, not by zooming in as in Google Earth. In what follows, I will accordingly present a preliminary history of cultural studies in Asia, Africa, and Latin America, identifying the salient debates across the regions, and then end with a discussion on the stakes of imagining planetary history from below.

\section{CULTURAL STUDIES AND THE GEOPOLITICS OF DECOLONIZATION IN ASIA}

Let me begin with the intersection of area studies and cultural studies. Lawrence Grossberg notes that cultural studies came "into existence in a wide range of geographies following the Second World War, each drawing on their traditions and each formulating unique questions for a politics of culture" (12). Grossberg's observation is relevant especially when one considers the case of cultural studies in Asia, which has drawn for the most part on various intellectual traditions of area studies. Cultural studies in Asia, broadly conceived, began as a product of and a response 
to the conditions of the Cold War. Long before the establishment of the Birmingham school, for instance, the Ford Foundation had funded a project in 1951 called the "Cultural Studies Project," a comparative study of civilizations that was done when notions of culture played a crucial part in post-war area studies dispensations. Using the framework of the Cold War, the study of the culture of others was understood as the domestication of their foreignness.

This framework, however, provided the conditions for its own critique. That is to say, when area studies became institutionalized as an academic discipline meant to maintain Cold War geopolitics, a space was opened up within the field in which critical forces also came to exist. In short, mostly white male Asianists like Denis Twitchett and Benedict Anderson had trained mostly male Asian scholars like Wang Gungwu and Reynaldo Ileto who then used their education for their own purposes. For both parties, culture occupied pride of place. If Fernand Braudel viewed the world according to a Western understanding of civilizations, Asian scholars accordingly appropriated the concept of "longue duree" to create civilizational narratives that viewed the world from their vantage point. ${ }^{5}$ Indeed, the turn toward indigenization, which coincided with the rise of Western-backed area studies in the region, developed in many parts of Asia. To cite one instance, the social sciences in Taiwan and Hong Kong underwent sinicization in the 1970s, a development that corresponded with the rise of multiculturalism in the United States. ${ }^{6}$ The indigenization movements, however, would be critiqued for being conservative and complicit mainly because the reactionary state was often responsible for promoting them into official state ideologies. Consider the Philippine case where Ferdinand Marcos commissioned Filipino historians to ghostwrite an indigenous historiography that lionized the dictator and his wife as mythical leaders. ${ }^{7}$ In cases like this, the intellectual project of the indigenous movement was co-opted to sustain the dubious ends of the reactionary state.

Such cases aptly illustrate the dangers of "civilizational argument," as Arif Dirlik puts it. Out of the shadows of such civilizational arguments, the contemporary critique of area studies has emerged, one of which is called critical Asian studies whose aim is to correct the complicit and conservative valorization of civilizational narratives. As Dirlik cogently notes, "what distinguishes contemporary critiques of area (and Asian) studies scholarship is not the critique of orientalism per se, which has been in question since the beginning, but rather the inclusion in the critique of radical alternatives to Orientalist culturalism of their Eurocentrism" (161). In other words, the contemporary critiques of indigenous movements are much more reflexive and strategic. According to Dirlik, the contemporary critiques are different because they go beyond the spatial imagination that is inherent in Cold War area studies, creating a new imaginary geography that takes into account the emergent global forces that shape the region. Part of this contemporary critique is the development of intellectual networks within Asia that foreground their interventions within 
the realities of the region. That is, the contemporary critiques of area and Asian studies highlight the importance of Asia without repeating the failures of early indigenization movements. One example that embodies the spirit of contemporary critiques is the academic journal Inter-Asia Cultural Studies. Based in the National Tsing Hua University in Taiwan and managed by an editorial collective that spans several Asian countries, the journal deals with so called inter-Asia processes and provides a critical forum for scholars working in cultural studies. In many ways, Inter-Asia Cultural Studies signifies the full integration of the legacies of area studies, especially those allied with contemporary critiques, and cultural studies itself. As such, the journal represents the routes of critical area studies whose roots have always been embedded in the study and politics of culture.

Today the future of Asian studies is increasingly tied to that of cultural studies. Consider Australia where scholars of Asia have come to embrace cultural studies. Analyzing the crisis of Asian studies in that part of the world, Chris Burgess suggests that its revitalization lies in recognizing the usefulness of cultural studies as a critical method and practice. "The central recommendation," he writes, "is the need to embrace more warmly the post-disciplinary fields of critical inquiry of which cultural studies is probably the best known" (133). Burgess draws his conclusions on the recent cultural turn that has influenced the major journals in the field, including the Bulletin of Concerned Asian Scholars that was transformed into Critical Asian Studies in 2001 to reflect the interdisciplinary nature of emerging scholarship. In Japan, the Institute of Oriental Culture at the University of Tokyo has inaugurated the International Journal of Asian Studies, which comes out of Cambridge University Press. Like Inter-Asia Cultural Studies, the International Journal of Asian Studies aspires to create "intra-Asian networks." ${ }^{8}$ In the Philippines, there is the electronic journal Kritika Kultura. The first of its kind in the country, the electronic journal combines critical area studies and cultural studies. Not surprisingly, it is based in the English department where most of its senior faculty members hold doctoral degrees in Philippine studies - a professoriate of English educated in the rhetoric of anti-colonialism itself. ${ }^{9}$

Dirlik would argue that journals like these call attention "to the possibilities and actualities of a radical oppositional politics - including the construction of areas from below" (167). As the founding editorial statement of Inter-Asia Cultural Studies makes clear, the political and economic "transformations across the region in the Post Cold War era have engendered both new social movements and critical cultural studies as forces of decolonization" (5). ${ }^{10}$ This is precisely the logic that informs one of the earliest anthologies in Asian cultural studies, Trajectories: Inter-Asia Cultural Studies. ${ }^{11}$ An anthology of essays originally presented at two international conferences in Taiwan, the book includes scholars from Australia, Indonesia, Taiwan, Singapore, Philippines, Korea, Canada, India, and the United States. A work in cultural studies, the anthology is also a manifesto of decolonization, espousing what Kuan-Hsing Chen calls "a politically-charged postcolonial 
cultural studies" (29) whose dream is to fulfill the unfinished project of decolonization. As we shall see, the decolonizing imperative and the contradictions of indigenization that shape cultural studies in Asia have implications that extend far beyond the region.

\section{CULTURAL STUDIES AND THE POLITICS OF INDIGENIZATION IN AFRICA}

Indeed, the questions that have bedeviled cultural studies in Asia are also the same quandaries shaping cultural studies in Africa. Take the case of indigenization, which is in fact the foundational issue that Ntongela Masilela had raised in his preface to one of the earliest critical anthologies on South African cultural studies, Keyan G. Tomaselli's Rethinking Culture. ${ }^{12}$ In particular, Masilela brought up the undue attention that cultural studies in South Africa gave to European intellectual history. Cultural studies in South Africa, he argued, disproportionately situated their concerns within the context of British cultural debates. "The fact of the matter," he wrote, "is that our historicalness lies mainly in our native cultural history" (2). He therefore concluded that the task for cultural studies in South Africa involved the "de-Europeanization and a thoroughgoing nativization and Africanization in its intellectual processes" (2).

Masilela's arguments reveal the decolonizing imperative, which is the same postcolonial critique animating the indigenization project in Asia. Needless to say, decolonization cannot be underestimated given the fact thatthe professional study of African culture and history, like most modern African states, is less than 50 years old. In the 1960s, for instance, African historians were writing history for self-government. ${ }^{13}$ African intellectuals were certainly facing a double burden - the burden of European colonial history and the burden of writing the unfolding history of decolonization. Seen thus, the work of decolonization is the cultural work of the postcolonial nation, an idea that has particularly preoccupied South African intellectuals that the 1960s had defined. This was the generation that moved out of the university to do radical organizing and went back to face new problems in the wake of the Apartheid. Such political developments eventually led to an Africa-focused intelligentsia, as Andre Du Toit would argue.

A special issue of Cultural Studies (2008) confronts the same subject and revives the need for indigenized cultural studies. ${ }^{14}$ In their introduction, Tomaselli and Handel K. Wright revisit the early days of the indigenization movement and stress the fact that its leading light, Masilela himself, had made that call as an exile in the United States, making it one of the first transnational interventions in the making of African cultural studies. For Tomaselli and Wright, Masilela's exilic indigenization underscores the relationship between African cultural studies and the transnational, signifying the kind of cultural studies that is contextual and inter-contextual. In other words, the transnational cultural studies that Tomaselli and Wright embrace is the kind that 
sees the transnational as vernacular. The transnational is the local by other means, a transnational vernacularism if you will. Seen this way, the transnational is not the opposite of the national. Instead, it signifies the commensurability of the local and the exilic whose result may be understood as the vernacularism of the transnational in which exiles dream their homelands into existence. In this paradigm, the transnational serves as the very condition for the possibility of vernacular imaginaries, a notion that returns us to the decolonizing imperative in which the work of culture is ultimately equated with the work of the postcolonial nation. Thus, the desire for the writing of history from below gestures toward the desire for the production of the intellectual as citizen, a condition that resonates in South Africa where a tradition of public intellectuals, including Eugene Marais and Mohandas Gandhi, exists. Given the popular and populist nature of the postcolonial task, cultural criticism has accordingly become the preferred style for African intellectuals.

Cultural studies in the context of decolonization therefore becomes a form of cultural criticism, the type associated with social criticism in which the fundamental social problems ailing the postcolonial nation are purposefully examined. Given the contemporary crisis of the postcolonial African nation, the function of cultural studies as cultural criticism becomes more urgent, as the special issue of Socialism and Democracy (2007) demonstrates. ${ }^{15}$ Among its contributors is Biodun Jeyifo who analyzes the last African half-century that he describes as the "arrested period of decolonization in the postindependence period" (125). He argues that culture has become one of Africa's last great hopes and suggests that it "constitutes the only real bulwark, the last redoubt, the kernel of both effective resistance to the West and neutralization of Africa's enormous disadvantage" (128). Like Tomaselli and Wright, Jeyifo assigns to culture the productive capacities of freedom and its realization. But Jeyifo cautions, like Frantz Fanon did before him, that the realization of freedom can take place only if the cultures of Africa are provided with a "national dimension" (141). What we find here is the idea of a political formation whose fate depends on the unity that culture provides. Hence, the unity of nation becomes the unity that culture allows. This idea is significant because of what it implies, that is, the decolonizing imperative has allowed cultural studies to exist as a form of cultural analysis. Cultural studies, then, has thrived in Africa and Asia because of the event of decolonization. In that sense, cultural studies as cultural criticism is the other name for the cultural work of the postcolonial nation, a notion that resonates well in the case of Latin America, as I will demonstrate shortly.

\section{CULTURAL STUDIES AND THE CRITIQQUE OF KNOWLEDGE-PRODUCTION IN LATIN AMERICA}

The conjunction of cultural criticism and nation-formation proves to be significant in Latin America where cultural studies had taken root because of its ideological affinity with the Latin 
American cultural essay whose practitioners include José Martí and Octavio Paz. In fact, the founding fathers of cultural studies in Latin America, such as Angel Rama and Antonio Candido, were doing cultural criticism as literary critics. Not surprisingly, Rama's posthumously published La Ciudad Letrada, a literary analysis of the role of cities in the reproduction of power, is considered a founding document of Latin American cultural studies. In the 1970s, an institution in Caracas would serve as an incubator of cultural studies as cultural criticism, the Fundación Centro de Estudios Latinoamericanos Rómulo Gallegos, where scholars from across the region had gathered to collaborate professionally and politically.

Over the years, however, the politics of knowledge-production would dominate the scene, creating intellectual and personal conflicts. The presence of competing narratives about cultural studies as a form of Latin American cultural criticism is a testament to this tension. Take the case of Nelly Richard who distinguishes cultural critique from cultural studies. For Richard, the terms represent theoretically different projects in that the former speaks from Latin America and embodies a Latin American approach, whereas the latter speaks about Latin America and is therefore a form of Latin Americanism, a distinction that brings to our mind the comparable tension between Asianists and Asian scholars. ${ }^{16}$ Ana Del Sarto suggests nonetheless that the two are equivalent categories. But Abril Trigo takes exception to her argument and points out the fact that the difference between Latin American cultural studies and traditional Latin American thought actually marks the difference between two ideological stances. Where Latin American cultural studies considers national literature as an apparatus of power, Latin American thought, Trigo would argue, affirms its unifying capacities.

The distinction is important. As Beatriz Sarlo argues, questions about location, that is, questions about the nation, might prove irrelevant to Latin Americanists, but they are essential to Latin American countries where US interests have decisive influence on local politics and economy. Thus, the nation as a political and cultural category remains indispensable. "[T]he cultural consequence of the nation's dissolution," Sarlo writes, "is not the emergence of a community empowered to invent new forms of action, but a disintegrated society" (338). In the end, the debate about location signifies Latin America's thorny relationship with its northern neighbor, and the distinctions being made about cultural studies as a form of cultural criticism reveal the bias against its perceived provenance as a critical practice. For a number of Latin Americans, cultural studies is suspect because it came to Latin America via the United States. ${ }^{17}$

Today, cultural critics in Latin America are confronting political questions head-on. Given the turn to the Left in Venezuela, Bolivia, and Ecuador, cultural thinkers now find themselves grappling with the crisis of neoliberal reforms that have been imposed on the region. Arturo Escobar provides a persuasive analysis of this issue, suggesting that the neoliberal debacle and 
popular embrace of the Left signal "the crisis of the project of bringing about modernity in the continent since the Conquest" (3). ${ }^{18}$ Escobar is addressing the contemporary crisis in Latin America, but I think his discussion reveals the salience of postcolonial critique in that he draws on the experiences of indigenous movements and Afro communities to imagine alternatives to Western models of development, one of which is the so called decolonial project that demands the radical rethinking of categories like power and life from the perspective of subordinated communities. In doing so, Escobar reminds us of the similar challenges that Asian and African indigenization movements have posed, respectively, to Western civilizational narratives and European intellectual history.

PORTENTS FROM THE ENDS OF THE PLANET

What, then, do we make of cultural studies as a postcolonial practice? As examples from Asia, Africa, and Latin America demonstrate, the rise of cultural studies in the global South not only coincides with decolonization, but also responds to its cultural imperatives, consequently clarifying the role of culture in the making of the postcolonial nation and its subjects. On the one hand, cultural studies is taken to be good because it provides the necessary conceptual form for the practice of decolonization. On the other, it is considered to be bad because it illustrates the consequences of cultural contact in which colonialism serves as the old model and globalization, the new. As we have seen, such polar views constitute the terms of the indigenization debates in the global South. More importantly, cultural studies has served as an important site for the elucidation of such disputes. Whether it is the geopolitics of decolonization in Asia, the politics of indigenization in Africa, or the critique of knowledge-production in Latin America, cultural studies signifies the unfinished task of decolonization.

Seen thus, postcolonial cultural studies is profoundly geopolitical in that it highlights the relation between knowledge and the sites of its production, a condition that the indigenization movements across the regions illustrate. This conclusion might seem commonplace, but I think it reveals the radical aspect of postcolonial cultural studies. That is to say, the critique of knowledge-production, which indigenization has occasioned, allows us to grasp nothing less than the rethinking and remaking of our geopolitical imagination. In other words, cultural studies as decolonization countenances the reformation of world-systems constituting the very foundations of Asianness, Africanness, and Latin Americanness as conceptual categories. Thus, cultural studies as postcolonial critique is a remaking of places, a reconstruction of the planet as we know it, one that demonstrates the planetary dimensions of vernacular practices. Such planetary reconstruction, as 
must be clear, comes from below. For that reason, the subaltern lies at the heart of cultural studies as a postcolonial practice. ${ }^{19}$

To the old question we must therefore add the new: can the subaltern rethink the planet? Considering the case of cultural studies in the global South, I hope to have demonstrated, however briefly, what totality can be like when imagined from below. More significantly, I hope to have contributed to the demythologization of what Mary Louise Pratt calls the monopolism of metropolitan enlightenment thought, which assumes that it alone can imagine the universal good. Nothing can be farther from the truth because humanity, as Pratt contends, can be totalized anywhere. Pratt instructs us, however, that a planetary optic from below must strive to be "superordinate to that of the enlightenment and of capitalism" (12). I like to think that postcolonial cultural studies is superordinate because it teaches us to totalize from a position of difference and dispossession, reminding us that the planetary does not name a flattened map of the same. Rather, it signifies the multitude that the planet contains.

Such planetary multitude denotes the existence of subalterns everywhere. As Jonathan Rutherford suggests, cultural studies has sought from the start to articulate the antagonisms of class, culture, and colonialism. The history of postcolonial cultural studies is the history of these planetary antagonisms. So much depends on the elaboration of this planetary history, which behooves us to imagine a new universalism that takes the condition of struggle and unfreedom as the site for imagining a new time and place for Guevarra's millions, now billions, of inhabitants of Asia, Africa, and Latin America. There is another way of saying this. If we allow the history of cultural studies beyond North America, Europe, and Australia to remain unwritten, we are allowing the silencing of peoples from the global South who comprise $84 \%$ of humanity today. The wretched billions stand to gain a planet and future by imagining otherwise. 


\section{NOTES}

The development of this article took place in multiple sites, including New Haven where the first ideas were formed during my conversations with Michael Denning and other members of the Working Group on Globalization and Culture; Tepoztlan where I benefitted from the thoughts of Renato Rosaldo, Mary Louise Pratt, and Kirsten Silva Gruesz at the Institute for Transnational History of the Americas; and Manila where I presented an early draft at a lecture in 2007 hosted by Kritika Kultura and its editor, Ma. Luisa Torres-Reyes. I also gained much from the suggestions of John Hartley. I am grateful to all of them.

Seen thus, the end of the Birmingham school marks the beginnings of a more capacious cultural studies in which the global comes to share the same lofty place that the national has long secured for itself.

The design of the anthology reflects its aim to pluralize and reveal the intellectual inheritances of cultural studies. The anthology is divided into topical sections with corresponding editors responsible for selecting and introducing the articles.

I am using the planet to distinguish it specifically from the global and transnational. A less contaminated conception of the world, the planet represents totalization with a difference. It is not an actually existing reality, but rather a political project whose utopian character is evidenced by the fact that it has yet to be defined by the Oxford English Dictionary. For an example of the planet as a critical term, see Paul Gilroy's Postcolonial Melancholia. An earlier use of the term can be found in Chakravorty Gayatri Spivak's Death of a Discipline. Recently, the planetary optic has been used in transnationalizing the study of American literature, an example of which can be found in Wai Chee Dimock's Through Other Continents: American Literature Across Deep Time.

For a response to the Annales School in the Philippines, see Zeus Salazar, The Malayan Connection: Ang Pilipinas sa Dunia Melayu. The case of indigenization in the Philippines has a complex history that I, unfortunately, cannot discuss given the limits of the article. For the deployment of "longue duree" in Chinese historiography, see Li Bozhong, Agricultural Development in Jiangnan, 1620-1850.

See Allen Chun and AB Shamsul's “Other 'Routes': The Critical Challenge for Asian Academia." For a critique of the current consequences of multiculturalism in the United States, see Timothy Brennan, Wars of Position: The Cultural Politics of Left and Right.

See Ferdinand E. Marcos, Tadhana: The History of the Filipino People.

See the editorial statement of the inaugural issue, "Introduction to Intra-Asian Networks."

Some of the older faculty of the department had actually published cultural criticism that could be regarded as prototypes of local cultural studies, including works by Doreen Fernandez on Filipino cuisine and Nicanor Tiongson on regional theater.

See the "Editorial Statement" of Inter-Asia Cultural Studies.

See the anthology edited by Kuan-Hsing Chen, Trajectories: Inter-Asia Cultural Studies, which is divided into three parts with the following subheadings: "Reconfiguring the Colonial," "Inside/ Outside the Nation/State," and "Renegotiating Movements," respectively. 
The anthology was originally conceived at a workshop that the Foundation for Education with Production had organized in 1983, which led later to the establishment of the Contemporary Cultural Studies Unit at the University of Natal in 1985, now known as the University of KwaZulu-Natal. The anti-Apartheid movement had been crucial to the making of the anthology whose aim was to popularize cultural studies as "one means to tackle the vast task of cultural reconstruction" (9). The anthology itself drew on the popular expressions and symbols of the anti-Apartheid movement, including pictures, artworks, posters, newspaper clippings, and editorial cartoons.

3 For a discussion of modern African history, see John Lonsdale, "Agency in Tight Corners: Narrative and Initiative in African History."

$4 \quad$ The special issue includes articles on black cinema, youth culture, popular music, Europe and African thought, performance, and South African cultural studies.

$5 \quad$ See the special issue of Socialism and Democracy on Africa, which includes articles on the politics of reconstruction, feminism and social democracy, and political philosophy, among others.

6 Interestingly enough, the same mistrust was felt when the Birmingham school arrived in the United States. African American scholars, for example, reacted disapprovingly to the introduction of racial and ethnic analyses associated with cultural studies. Like the Latin American case, African American scholars tried to distinguish black studies from cultural studies and its hybrid, black cultural studies. The historical precedents of black studies in the United States go as far back as the $19^{\text {th }}$ century, while black cultural studies existed only in the late 1980s and early 1990s. Mae Henderson would argue that black cultural studies uses paradigms that are not specific to African American history and culture. But the fact remains that cultural studies has changed Latin American studies, altering its conventional assumptions about culture and literature, as Mabel Moraña argues.

8 The postcolonial critique, however, is much more explicit in the volume that Escobar has co-edited with Walter Mignolo called Globalization and the Decolonial Option, which originally came out as a special issue of Cultural Studies. In this publication, Escobar and Mignolo propose the project of decolonizing knowledge.

9 Indeed, the subaltern is an important keyword in cultural studies in the global South. To cite two examples, the Latin American Subaltern Studies Association was established in the United States in 1992, whereas Stratton and Ang would argue in a different context that cultural studies in Taiwan might be described as subaltern in relation to its Anglo-American counterparts. 


\section{WORKS CITED}

Abbas, Ackbar, and John Nguyet Erni, eds. Internationalizing Cultural Studies: An Anthology. Oxford: Blackwell, 2005.

Bozhong, Li. Agricultural Development in Jiangnan, 1620-1850. New York: St. Martin's, 1998.

Braudel, Fernand. Civilisation Matérielle, Économie et Capitalisme, XVe-XVIIIe Siècle. Paris: Armand Colin, 1979.

Brennan, Timothy. Wars of Position: The Cultural Politics of Left and Right. New York: Columbia UP, 2005.

Burgess, Chris. “The Asian Studies 'Crises': Putting Cultural Studies Into Asian Studies and Asia Into Cultural Studies." International Journal of Asian Studies 1.1 (2004): 121-36.

Chen, Kuan-Hsing, ed.Trajectories: Inter-Asia Cultural Studies. London: Routledge, 1998.

Chun, Allen, and AB Shamsul. "Other 'Routes': The Critical Challenge for Asian Academia." Inter-Asia Cultural Studies 2.2 (2001): 167-76.

Del Sarto, Ana. “Cultural Critique in Latin America or Latin-American Cultural Studies?” Journal of Latin American Cultural Studies 9.3 (2000): 235-47.

Denning, Michael. Culture in the Age of Three Worlds. London: Verso, 2004.

Dimock, Wai Chee. Through Other Continents: American Literature Across Deep Time. Princeton: Princeton UP, 2008.

Dirlik, Arif. "Asia Pacific Studies in an Age of Global Modernity." Inter-Asia Cultural Studies 6.2 (2005): 158-70.

Du Toit, Andre. "Critic and Citizen: The Intellectual, Transformation, and Academic Freedom." Pretexts: Literary and Cultural Studies 9.1 (2000): 91-104.

Editorial Statement. Inter-Asia Cultural Studies 1.1 (2000): 5-6.

Editorial Statement. International Journal of Asian Studies 1.1 (2004): 3.

Escobar, Arturo. “Latin America at a Crossroads: Alternative Modernizations, Post-Liberalism, or PostDevelopment?" Cultural Studies (2010): 1-65.

Fernandez, Doreen, and Edilberto Alegre. Sarap: Essays on Philippine Food. Manila: Mr. \& Ms., 1988.

Gilroy, Paul. Postcolonial Melancholia. New York: Columbia UP, 2005.

Grossberg, Lawrence. “Does Cultural Studies Have Futures? Should It? (Or What's the Matter with New York?)" Cultural Studies 20.1 (2006): 1-32.

Guevarra, Che. "Colonialism is Doomed." General Assembly of the United Nations in New York. 11 Dec. 1964. 14 July 2011<http://www.marxists.org/archive/guevara/1964/12/11.htm>.

Henderson, Mae. “'Where, By the Way, is This Train Going?' A Case for Black (Cultural) Studies.” Callaloo 19.1 (1996): 60-67.

Jeyifo, Biodun. "An African Cultural Modernity: Achebe, Fanon, Cabral, and the Philosophy of Decolonization." Socialism and Democracy 21.3 (2007): 125-41.

Lonsdale, John. "Agency in Tight Corners: Narrative and Initiative in African History." Journal of African Cultural Studies 13.1 (2000): 5-16.

Marcos, Ferdinand E. Tadhana: The History of the Filipino People. Manila: S.N., 1976.

Masilela, Ntongela. "Preface: Establishing an Intellectual Bridgehead." Rethinking Culture. Ed.

KeyanTomaselli. Bellville, South Africa: Anthropos, 1988. 
Mignolo, Walter, and Arturo Escobar, Globalization and the Decolonial Option. New York: Routledge, 2009.

Moraña, Mabel. “Latin American Cultural Studies: When, Where, Why?” Hispanic Issues (2006): 31-35.

Moretti, Franco. "Conjectures on World Literature." New Left Review (2000): 54-68.

Pratt, Mary Louise. "Planetary Longings: Sitting in the Light of the Great Solar TV." Tepoztlan Institute for Transnational History of the Americas, Tepoztlan, Mexico. 24 July 2008.

Rama, Angel. La Ciudad Letrada. Montevideo, Uruguay: Comision Uruguay apor Fundación Internacional Angel Rama, 1984.

Richard, Nelly. "Intersectando Latinoamémerica el Latinoamericanismo: Discurso Académeco y Crítica Cultural." RevistaIberoamericana (1997): 345-61.

Rutherford, Jonathan. "Cultural Studies in the Corporate University." Cultural Studies 19.3 (2005): 297-317.

Salazar, Zeus. The Malayan Connection: Ang Pilipinas sa Dunia Melayu. Quezon City: Palimbagan ng Lahi, 1998.

Sarlo, Beatriz. "Cultural Studies: Reworking the Nation, Revisiting Identity." Journal of Latin American Cultural Studies 11.3 (2002): 73-93.

Spivak, ChakravortyGayatri. Death of a Discipline. New York: Columbia UP, 2003.

Stratton, Jon, and Ien Ang. "On the Impossibility of a Global Cultural Studies: 'British Cultural Studies' in an 'International' Frame.” Stuart Hall: Critical Dialogues in Cultural Studies. Eds. David Morley and KuanHsing Chen. London: Routledge, 1996.

Tiongson, Nicanor. Kasaysayan at Estetikang_Sinakulo at Ibang_Dulang_Panrelihiyon_sa_Malolos. Quezon City: Ateneo de Manila UP, 1975.

Tomaselli, Keyan G., and Handel K. Wright, eds. Cultural Studies 22.2 (2008).

Trigo, Abril. “Why Do I Do Cultural Studies?” Journal of Latin American Cultural Studies 9.1 (2000): 73-93. 